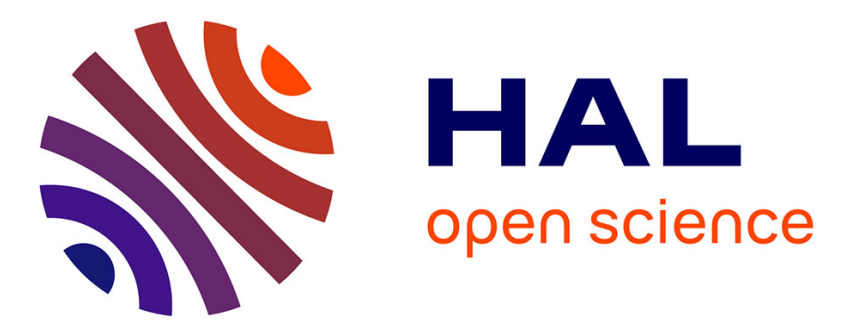

\title{
The large-scale water cycle of the West African monsoon
}

Olivier Bock, F. Guichard, Remi Meynadier, Sébastien Gervois, A. Agustí-Panareda, A. Beljaars, A. Boone, M. Nuret, J.-L. Redelsperger, P. Roucou

\section{- To cite this version:}

Olivier Bock, F. Guichard, Remi Meynadier, Sébastien Gervois, A. Agustí-Panareda, et al.. The largescale water cycle of the West African monsoon. Atmospheric Science Letters, 2011, 12 (1), pp.51-57. 10.1002/asl.288 . hal-00548132

\section{HAL Id: hal-00548132 https://hal.science/hal-00548132}

Submitted on 10 Jan 2021

HAL is a multi-disciplinary open access archive for the deposit and dissemination of scientific research documents, whether they are published or not. The documents may come from teaching and research institutions in France or abroad, or from public or private research centers.
L'archive ouverte pluridisciplinaire HAL, est destinée au dépôt et à la diffusion de documents scientifiques de niveau recherche, publiés ou non, émanant des établissements d'enseignement et de recherche français ou étrangers, des laboratoires publics ou privés. 


\title{
The large-scale water cycle of the West African monsoon
}

\author{
O. Bock, ${ }^{1,2 *}$ F. Guichard, ${ }^{3}$ R. Meynadier, ${ }^{2}$ S. Gervois, ${ }^{2}$ A. Agustí-Panareda, ${ }^{4}$ A. Beljaars, ${ }^{4}$ A. Boone, ${ }^{3}$ M. Nuret, ${ }^{3}$ \\ J.-L. Redelsperger ${ }^{3}$ and P. Roucou ${ }^{5}$ \\ 'LAREG, IGN, Marne-la-Vallée, France \\ ${ }^{2}$ LATMOS, CNRS, Université de Paris 6, Paris, France \\ ${ }^{3}$ GAME-CNRM, CNRS, Météo-France, Toulouse, France \\ ${ }^{4} E C M W F$, Reading, UK \\ ${ }^{5}$ CRC, CNRS, Université Dijon, Dijon, France
}

*Correspondence to:

O. Bock, Laboratoire de

Recherche en Geodesie, Institut

Geographique National,

ENSG - Cite Descartes, 6-8

Avenue Blaise Pascal, Champs

sur Marne, F77455

Marne-la-Vallée cedex 2, France.

E-mail: Olivier.Bock@ign.fr

Received: 10 February 2010

Revised: 2 July 2010

Accepted: 16 July 2010

\begin{abstract}
The vertically integrated water budget of West Africa is investigated with a hybrid dataset based on observational and modelling products elaborated by the African Monsoon Multidisciplinary Analyses (AMMA) and with several numerical weather prediction (NWP) products including the European Centre for Medium-Range Weather Forecasts (ECMWF) AMMA reanalysis. Seasonal and intraseasonal variations are quantified over the period 2002-2007. Links between the budget terms are analyzed regionally, from the Guinean coast to the Sahel zone. Water budgets from the NWP systems are intercompared and evaluated against the hybrid dataset. Large deficiencies are evidenced in all the NWP products. Hypotheses are proposed about their origins and several improvements are foreseen. Copyright (C) 2010 Royal Meteorological Society
\end{abstract}

Keywords: AMMA; water budget; GPS; numerical weather prediction; West African monsoon; water cycle

\section{Introduction}

The large-scale water cycle of West Africa results from the interplay of various coupled ocean-atmosphereland surface processes. The identification of the mechanisms involved and the scales at which they operate is a major objective of the African Monsoon Multidisciplinary Analyses (AMMA) (Redelsperger et al., 2006). Before the AMMA, only a few studies focused specifically on the West African monsoon (WAM) water cycle. These studies satisfactorily revealed several key elements determining the seasonal cycle of precipitation and the water cycle of West Africa, such as the role of moisture transported by the southwesterly low-level monsoon flow and the mid-level African easterly jet (Cadet and Nnoli, 1987; Nicholson et al., 1997; Fontaine et al., 2003). Synoptic variability was also evidenced in the moisture fluxes at space- and timescales corresponding to African easterly waves (Cadet and Nnoli, 1987). However, only a few studies focused specifically on regional-scale water budgets (Brubaker et al., 1993; Gong and Eltahir, 1996). Moreover, very contrasting results were found about the mechanisms involved at the seasonal and multi-annual timescales. A major reason for this lack of consensus is the variety and composite nature of data sources used. Among the different budget terms used in these studies, evapotranspiration appears as the most uncertain (Meynadier et al., 2010a). Furthermore, a few other key timescales were almost not addressed so far (e.g. the diurnal cycle and intraseasonal variability).

Numerical weather prediction (NWP) products have been often used for computing the atmospheric part of the water budget at global and regional scales and quantifying variability at intraseasonal to interannual timescales (Trenberth and Guillemot, 1995; Roads et al., 2002; Fontaine et al., 2003). However, NWP products rely heavily on physical parameterizations, especially in the Tropics, and on observational data. In recent years, new precipitation products and improved NWP model reanalyses have become available. However, overall, an unprecedented experimental and modelling effort was realized during the AMMA. This was centred on 2006 with the Special Observing Period (SOP), but many observing networks operated in enhanced mode from 2005 to 2007 and beyond.

This paper gives an overview of the large-scale continental water cycle studies conducted in the AMMA. It covers mainly the intraseasonal to interannual timescales of the atmospheric water budget using two different approaches. A hybrid dataset was developed by Meynadier et al. (2010a), which benefited from the AMMA Land surface Model Intercomparison Project (ALMIP) (Boone et al., 2009). This approach provides an advanced, comprehensive atmospheric water budget, including evapotranspiration, rainfall, atmospheric moisture flux convergence, together with other surface fluxes, such as runoff, soil moisture tendency and net radiation. In the second approach, several 
NWP model reanalyses have been used and intercompared with respect to the water budget. Given that the radiosondes in Africa had large humidity biases (Bock et al., 2007, 2008; Bock and Nuret, 2009; Nuret et al., 2008), a special reanalysis was also run at the ECMWF in which a new radiosonde humidity bias correction method was applied and many additional offline data were assimilated (Agustí-Panareda et al., 2009a, 2009b).

Some work in the AMMA also investigated the oceanic water cycle. Namely, Marullo et al. (2009) stressed the significance of the diurnal cycle in sea surface temperature which could be important to properly simulate the mean state and variability of the WAM circulation. This appears as another promising tool to study the WAM water cycle.

\section{Data and methods}

The vertically integrated atmospheric water budget equation can be summarized as (Trenberth and Guillemot, 1995)

$$
\mathrm{dPW}+\mathrm{MFD}=E-P
$$

where $E$ is the evapotranspiration from the surface, $P$ is the precipitation at the surface, dPW is the precipitable water vapour (PWV) tendency and MFD is the moisture flux divergence.

NWP models provide estimates for all terms intervening in Equation (1) in the form of forecasted variables. Analyzed variables (wind and humidity) allow also dPW and MFD terms to be computed. The computation of water budgets from NWP products suffers from various and different error sources whether one considers forecasts (FC) or analyses (AN). The forecast budget is closed, i.e. $\mathrm{dPW}_{\mathrm{FC}}+$ $\mathrm{MFD}_{\mathrm{FC}}=E_{\mathrm{FC}}-P_{\mathrm{FC}}$, but the balance between terms can be quite unrealistic, considering for example, drifts and spin up/down effects noticed in P, PWV and in atmospheric circulation in the Tropics. Also, the convection scheme has limited performance in the Tropics leading to biases in $P_{\mathrm{FC}}$. On the other hand, dPW and MFD terms can also be computed from analyzed data. They are usually more accurate in the sense they are closer to observations than forecasts are. However, the direct computation of MFD also introduces spatial and temporal sampling errors. Although there are some advantages of using NWP analyses, they do not provide estimates for $E$ and $P$. Combining the $\mathrm{dPW}_{\mathrm{AN}}$ and $\mathrm{MFD}_{\mathrm{AN}}$ with $E_{\mathrm{FC}}$ and $P_{\mathrm{FC}}$ is one possible way to investigate the full water budget, but it has a major drawback. Indeed, the data assimilation operation introduces corrections (increments) to a short-term forecast used as first guess. Hence, the combined AN/FC budget is not closed: $\mathrm{dPW}_{\mathrm{AN}}+\mathrm{MFD}_{\mathrm{AN}} \neq E_{\mathrm{FC}}-P_{\mathrm{FC}}$. This is especially true in the case of the ECMWF used in the present study extending from +12 to $+36 \mathrm{~h}$ ahead.

The hybrid dataset provides a different, nearly independent water budget dataset. Surface water and energy budget terms were simulated with nine land surface models (LSMs) forced with satellite precipitation (TRMM 3B42) and radiation products, with the same land surface characteristics (Boone et al., 2009). The nine $E$ estimates were averaged and combined with the forcing precipitation data, $P$ from TRMM and dPW from ECMWF Reanalysis (ERA)-Interim reanalysis, to yield MFD as a residual from the budget equation (so-called hybrid MFD)

$$
\mathrm{MFD}_{\mathrm{hyb}}=E_{\mathrm{LSM}}-P_{\mathrm{sat}}-\mathrm{dPW}_{\mathrm{NWP}}
$$

According to Meynadier et al. (2010a), the hybrid water budget dataset set-up during the AMMA is more accurate than the datasets used in previous studies, especially for the $E$ and MFD terms. These authors estimated the dispersion between several satellite precipitation products to $\pm 1 \mathrm{~mm}$ day $^{-1}$ for monthly means over areas of $\sim 3 \cdot 10^{6} \mathrm{~km}^{2}$ during the core of the monsoon. They also showed that the errors in $E_{\mathrm{LSM}}$ are correlated with the errors in $P_{\text {sat }}$ and are hence of similar magnitude. The multi-model approach used in the ALMIP (Boone et al., 2009) shows that the uncertainty in $E_{\mathrm{LSM}}$ (estimated based on intermodel spread) is relatively low compared to the other surface water and energy budget terms. In addition, comparisons to independent observations indicate that estimates of $E_{\mathrm{LSM}}$ may be significantly improved compared to those from past studies. The errors in $\mathrm{MFD}_{\text {hyb }}$ and $\mathrm{dPW}_{\mathrm{NWP}}$ are also very small $\left(\sim 0.2 \mathrm{~mm} \mathrm{day}^{-1}\right)$ at the monthly mean scale. Presently, this dataset covers the period 2002-2007.

The Global Positioning System (GPS) PWV observations (Bock et al., 2008) also represent a useful independent dataset which was used extensively for the validation of NWP products and radiosonde data at various timescales.

\section{Results}

\section{I. Verification of NWP analyses and radiosonde data with GPS PWV data}

Figure 1 presents an example of comparison of PWV variability at timescales from diurnal to seasonal cycles for three reanalyses and ECMWF-Integrated Forecast System (IFS) operational analysis. All the analyses show good agreement with GPS at timescales more than 2 days but perform very poorly for the diurnal cycle. ERA-Interim shows the best results followed by ECMWF-IFS. The average biases are small, except for NCEP Reanalysis II (NCEP2) which is too moist. At individual sites, biases can reach $\pm 3 \mathrm{~kg} \mathrm{~m}^{-2}$ or $\pm 20 \%$ PWV. Bock et al. (2007, 2008), found similar results for the ERA-40 reanalysis and the ARPEGE operational analysis. Bock and Nuret (2009), 




Figure I. Comparison of temporal variability of precipitable water vapour (PWV) from GPS and numerical weather prediction (NWP) models (from left to right: ECMWF-IFS, ERA-Interim, NCEP-RI, NCEP-R2), overaged over seven sites and period 2005-2008. Data were filtered according to the timescales of different processes: diurnal cycle (0.25-I day), synoptic disturbances ( $2-6$ days), short and long intraseasonal variations (6-24 and 30-90 days, respectively) and seasonal ( $>90$ days). The plots show (a) the standard deviation of PWV from NWP models, (b) the standard deviation of differences (PWV from model minus PWV from GPS), (c) ratio of standard deviations (model over GPS) and (d) correlation coefficient between model and GPS.
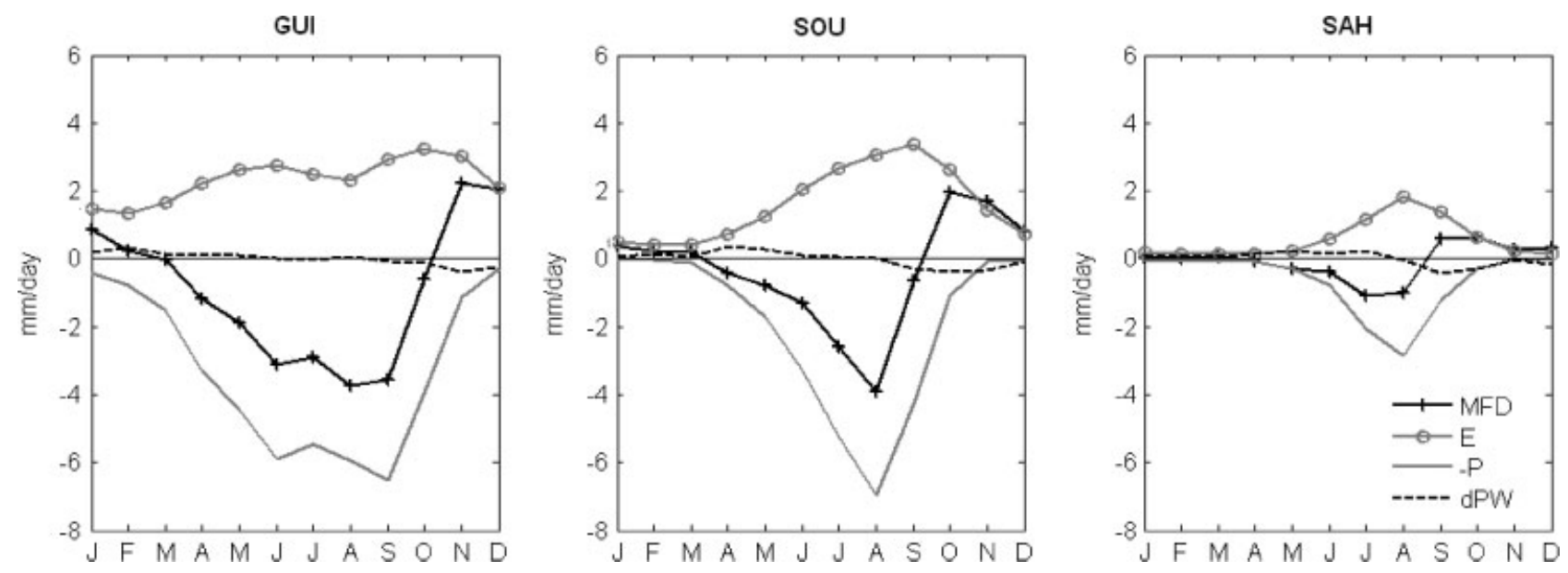

Figure 2. Seasonal cycle of the water budget from the hybrid dataset, in three latitude bands: GUI $\left(6-10^{\circ} \mathrm{N}\right), \mathrm{SOU}\left(10-15^{\circ} \mathrm{N}\right)$ and SAH $\left(15-20^{\circ} \mathrm{N}\right)$, all terms are monthly mean values averaged between $10^{\circ} \mathrm{W}$ and $10^{\circ} \mathrm{E}$, and over the years $2002-2007$.

established a link between radiosonde humidity biases and biases in NWP model analyses. In some occasions, radiosonde dry biases $>7 \mathrm{~kg} \mathrm{~m}^{-2}$ were found with old Vaisala RS80 sondes at daytime (e.g. in Tombouctou and Niamey).

Meynadier et al. (2010a) also evaluated dPW from several reanalyses with GPS observations and estimated uncertainties in dPW of $5-6 \mathrm{~mm} \mathrm{day}^{-1}$ at daily timescales and $0.15-0.35 \mathrm{~mm} \mathrm{day}^{-1}$ at monthly timescales, locally.

Agustí-Panareda et al. (2009a) showed that a new ECMWF radiosonde humidity bias correction tailored for the AMMA radiosonde data was effective at reducing the radiosonde bias. Data impact experiments showed that the radiosonde bias correction combined with the additional AMMA SOP data in 2006 improved the quality of ECMWF analyses (Agustí-Panareda et al., 2010). However, forecasts were only improved slightly and large model biases persist (e.g. temperature and humidity in the Sahelian boundary layer and strength of the African easterly jet).

\subsection{The hybrid water budget}

Meynadier et al. (2010a) analyzed the water budget terms for three latitudinal boxes between $6^{\circ} \mathrm{N}$ and $20^{\circ} \mathrm{N}$ referred to as GUI, SOU and SAH boxes. Figure 2 presents the seasonal cycle of the four budget terms of Equation (2) in the three boxes. It can be seen that West Africa is alternatively a source $(E-P>0$ during dry season) and sink $(E-P<0$ during wet season) of moisture for the atmosphere. The magnitude 
of the terms and balance between them is different in the different boxes. The annual mean $E-P \approx 0$ in the SAH box is largely endorheic. In the exorheic SOU and GUI boxes, $E-P<0$. Several limiting and controlling factors of the regional water cycle were evidenced by Meynadier et al. (2010a). The relationship between evapotranspiration and precipitation was shown to be very different between the Sahel zone and the regions more towards the South and partly controlled by the net surface radiation. Strong correlations between precipitation and moisture flux convergence were found over the whole region from daily to interannual timescales and causality among monthly mean anomalies was established. Namely, precipitation anomalies were shown to be preceded by moisture flux convergence anomalies and followed by MFD and evapotranspiration anomalies.

\subsection{Water budgets from NWP products}

Meynadier et al. (2010b) intercompared water budget terms from three global reanalyses, ERA-Interim and NCEP reanalysis I and II, and compared them to the hybrid water budget dataset at regional scales and to GPS dPW observations at local scales. Biases were evidenced in all three reanalyses in precipitation and evapotranspiration. Both quantities are too strong near the Guinean coast and too weak over the Sahel zone. Moreover, the reanalyses provide an unrealistic view of continental West Africa as a moisture source for the atmosphere $(E-P>0)$ north of $10^{\circ} \mathrm{N}$. These biases are consistent with those diagnosed in past studies, although in the case of ERA-Interim the model is based on a more recent physics. Meynadier et al. (2010b), completed their study with operational products (analyses and forecasts) from ECMWF-IFS, NCEP-GFS and ARPEGE-Tropique in 2006 and with the special ECMWF AMMA reanalysis. These more recent NWP systems exhibited similar features as the reanalyses. Figure 3 shows time-latitude diagrams of $E-P$ and $P$ from all the models and the hybrid dataset for comparison. In the ECMWF model forecasts (IFS, ERA-Interim and AMMA reanalysis) and in NCEP reanalyses, $E-P>0$ is especially marked during the dry season and in the northern part of the domain. This occurs in a region where soil moisture is quite low during the dry season (Figure 2). It suggests that evapotranspiration and precipitation processes are poorly coupled in these NWP systems. At least, in the ECMWF AMMA reanalysis, Agustí-Panareda et al. (2009b) detected large positive soil moisture analysis increments (i.e. moisture is added to the subsurface at each analysis) which produce excessive evapotranspiration in the subsequence short-term forecasts. The increments are due to biases in temperature and humidity at $2 \mathrm{~m}$ in the first guess. Large biases in the surface radiation budget in the ECMWF-IFS and ECMWF AMMA reanalysis forecasts were also detected by Guichard et al. (2010) and Agustí-Panareda et al. (2009b). These may result from biases in the used aerosol climatology and a lack of clouds in the forecasts over the Sahel zone that were diagnosed by Agustí-Panareda et al. (2009b), with independent observations (aerosol optical depth from AERONET photometers and clouds
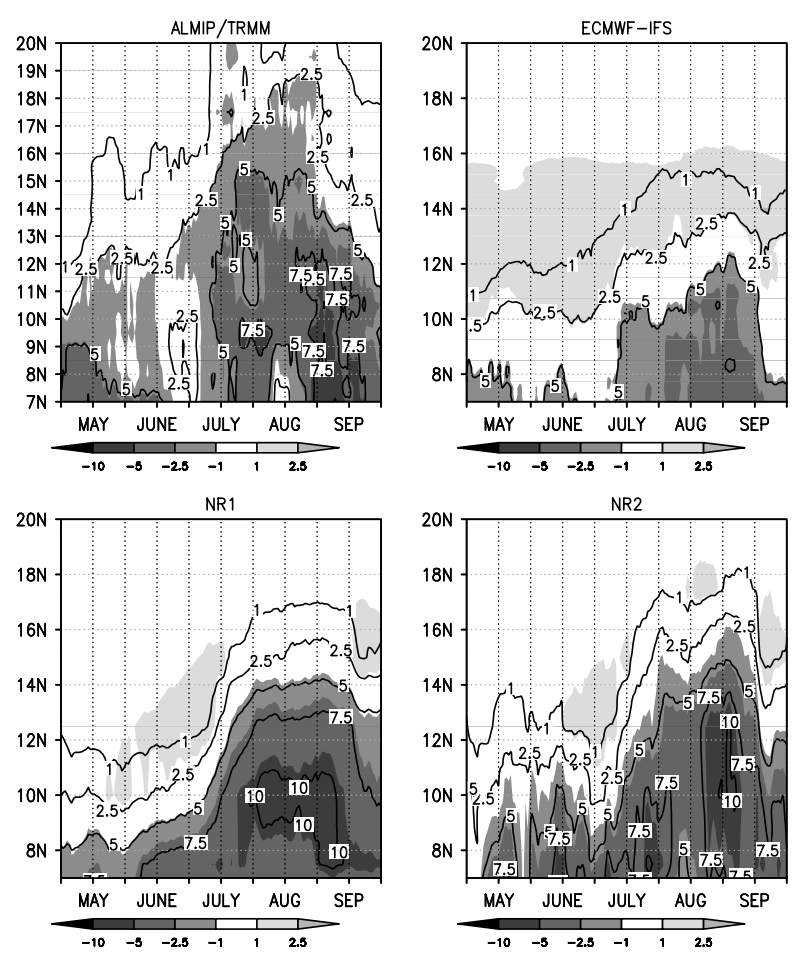


Figure 3. Latitude-time diagram of $E-P$ (shaded) and $P$ (contour) from the hybrid dataset (ALMIP/TRMM) and from seven numerical weather prediction (NWP) models (simulated variables), averaged over $10^{\circ} \mathrm{W}-10^{\circ} \mathrm{E}$ and over period from May to September 2006. 

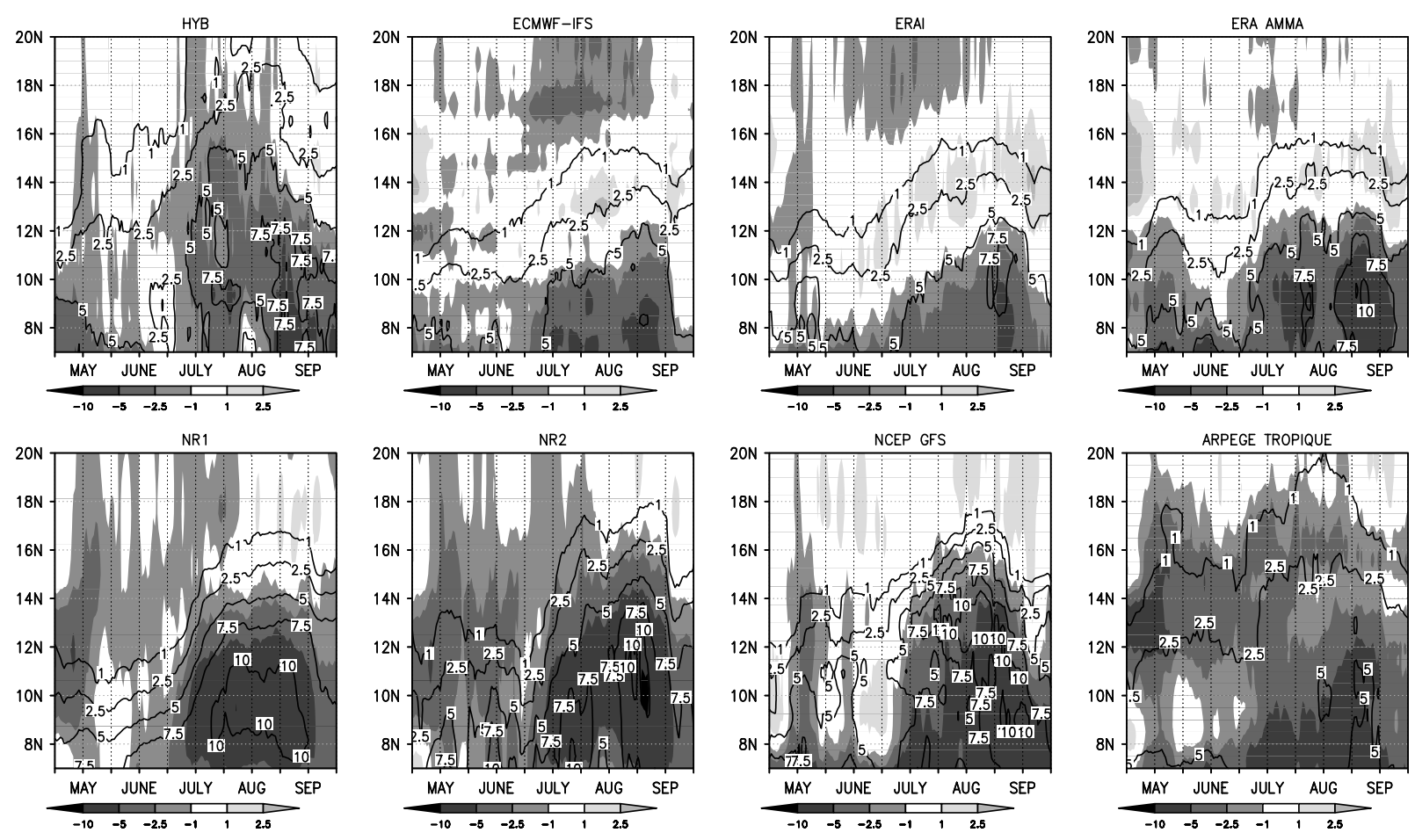

Figure 4. Similar to Figure 3 but for moisture flux divergence (MFD) (shaded) computed from analyzed variables and $P$ (contour) from simulated variables in the case of numerical weather prediction (NPW) systems. The MFD estimate from the hybrid dataset is computed as a residual from the budget in Equation (2).

from CALIPSO and CloudSat satellites observations). In NCEP-GFS, $E-P<0$, but $P$ is much too strong, and in ARPEGE-Tropiques both $E$ and $P$ are too weak. All these NWP systems thus have difficulties in representing properly $E$ and $P$ over West Africa. These results suggest that convection parameterizations may not be adequate.

Figure 4 compares vertically integrated moisture flux convergence computed from the analysis products of the various NWP systems. Depending on the NWP system, a minimum of convergence or divergence is seen north of the rainband $\left(13-16^{\circ} \mathrm{N}\right)$. This is not seen in the hybrid dataset. Inspection of vertical profiles reveals that this feature is mostly located in the low levels $(1000-800 \mathrm{hPa})$ at the southern branch of an overturning shallow meridional circulation (SMC) that is driven by the Saharan heat-low to the north (Meynadier et al., 2010b). This circulation appears too strong in the ECMWF model (either IFS, ERA-Interim or the AMMA reanalysis), leading to subsidence and MFD around $15^{\circ} \mathrm{N}$ in August. The origin of this enhanced SMC is attributed to the biases identified in the surface energy budget in the ECMWF model. Inspection of ERA-40 and changes in ECMWF-IFS since 2002, namely, in the aerosol climatology, tends to confirm this hypothesis. It is also hypothesized that this feature added to the presence of a deep layer of northerly dry air advected at mid-levels (800-400 hPa) might block the development of deep convection in the model forecasts and hence hamper the northward propagation of the rain belt. A too strong SMC seems to be present in all the NWP systems investigated in this study.

\section{Discussion and conclusions}

The hybrid dataset was useful in diagnosing the strength of several mechanisms of the WAM water cycle not clearly established from previous work (Meynadier et al., 2010a). Namely, links between $E$ and $P$, and $P$ and MFD, were shown to be different in the Sahel zone and more to the south revealing different surface-vegetation-atmosphere couplings and marked seasonal cycle and interannual variability (not shown here). Ongoing work is focused on shorter timescales at which this dataset is pertinent too, namely, the intraseasonal variability, synoptic scale and diurnal cycle. At smaller spatial scales, GPS dPW estimates also provide a means for investigating the water budget associated with Mesoscale Convective Systems (MCSs).

The hybrid dataset was also useful for evaluating NWP products (Meynadier et al., 2010b). It allowed the magnitude of a number of deficiencies in $P, E$ and MFD terms from analyses, forecasts and reanalyses to be confirmed and quantified. Significant closure errors (1-2 $\mathrm{mm} \mathrm{day}^{-1}$ ) were found, whatever the combination of NWP products (analyses and forecasts) and hybrid products $\left(P_{\text {sat }}\right.$ and $\left.E_{\mathrm{LSM}}\right)$. Nevertheless, reanalyses may allow interannual monthly mean anomalies to be estimated with more confidence over the region. NWP systems also give insight into the vertical 
dimension of the water cycle. Another independent method based only on observations, especially radiosonde data, is also under development (D. Bouniol, personal communication). This method is expected to provide an accurate vertical description of the water and energy budget at mesoscales during the SOP.

The NWP model intercomparison and comparison with products elaborated by AMMA provided insight into the origin of the model's deficiencies. These are mainly the convection scheme, soil moisture initialization and radiosonde humidity biases. Experiments conducted with the AMMA reanalysis showed that the recent improvements in convection scheme and radiosonde humidity bias correction slightly improved the water budget forecasts in the ECMWF model: the rain belt moved $1^{\circ}$ to the north, and $\mathrm{dPW}$ and MFD biases were slightly reduced (Agustí-Panareda et al., 2009b). Experiments with soil moisture initialized from ALMIP offline LSM simulations also slightly improved the forecast (Agustí-Panareda et al., 2009c). However, the gross biases highlighted above were still present. More work is needed to further improve the water cycle simulated by NWP models over West Africa. The most promising improvements are expected from an advanced modelling of interactions between surface, aerosols, convective clouds and radiative processes. Assimilation of new satellite data sensitive to lower tropospheric humidity and soil moisture are also expected to participate efficiently to the improvement of the water cycle in these models (De Rosnay et al., 2008; Karbou et al., 2010).

Future work should also consider the role of surrounding oceans, namely, quantifying the amount of moisture of oceanic origin transported towards West Africa and estimating the strength of continental water recycling.

\section{Acknowledgements}

The support of the AMMA project is gratefully acknowledged (see http://onlinelibrary.wiley.com/doi/10.1002/asl.331/full for full acknowledgement).

\section{References}

Agustí-Panareda A, Vasiljevic D, Beljaars A, Bock O, Guichard F, Nuret M, Lafore J-P, Andersson E, Bechtold P, Fink A, Hersbach H, Garcia Mendez A, Ngamini J-B, Parker DJ, Redelsperger J-L, Tompkins A. 2009a. Radiosonde humidity bias correction over the West African region for the special AMMA reanalysis at ECMWF. Quarterly Journal of the Royal Meteorological Society 135: 595-617.

Agustí-Panareda A, Beljaars A, Ahlgrimm M, Balsamo G, Bock O, Forbes R, Ghelli A, Guichard F, Köhler M, Meynadier R, Morcrette J-J. 2009b. The ECMWF re-analysis for the AMMA observational campaign. Quarterly Journal of the Royal Meteorological Society, DOI: 10.1002/qj.662 (in press).

Agustí-Panareda A, Balsamo G, Beljaars A. 2009c. Impact of improved soil moisture on the ECMWF precipitation forecast in
West Africa. Geophysical Research Letters (submitted). Available also as ECMWF Technical Memorandum Nr 611, pp 9.

Agustí-Panareda A, Beljaars A, Cardinali C, Genkova I, Thorncroft C. 2010. Impact of assimilating AMMA SOP soundings on ECMWF analyses and forecasts. Weather and Forecasting DOI: 10.1175/2010WAF2222370.1 (in press).

Bock O, Nuret M. 2009. Verification of NWP model analyses and radiosonde humidity data with GPS precipitable water vapor estimates during AMMA. Weather and Forecasting 24: 1085-1101. DOI: 10.1175/2009WAF2222239.1.

Bock O, Bouin M-N, Walpersdorf A, Lafore JP, Janicot S, Guichard F, Agustí-Panareda A. 2007. Comparison of ground-based GPS precipitable water vapour to independent observations and numerical weather prediction model reanalyses over Africa. Quarterly Journal of the Royal Meteorological Society 133: 2011-2027. DOI: $10.1002 / q j .185$

Bock O, Bouin MN, Doerflinger E, Collard P, Masson F, Meynadier R, Nahmani S, Koité M, Gaptia Lawan Balawan K, Didé F, Ouedraogo D, Pokperlaar S, Ngamini J-B, Lafore JP, Janicot S, Guichard F, Nuret M. 2008. The West African Monsoon observed with ground-based GPS receivers during AMMA. Journal of Geophysical Research 113: D21105. DOI:10.1029/2008JD010327.

Boone A, De Rosnay P, Basalmo G, Beljaars A, Chopin F, Decharme B, Delire C, Ducharne A, Gascoin S, Grippa M, Guichard F, Gusev Y, Harris P, Jarlan L, Kergoat L, Mougin E, Nasonova O, Norgaard A, Orgeval T, Ottlé C, Poccard-Leclercq I, Polcher J, Sandholt I, Saux-Picart S. 2009. The AMMA land surface model intercomparison project. Bulletin of the American Meteorological Society. Early online release, posted July 2009. 90: pp. 1865-1880, DOI: 10.1175/2009BAMS2786.1.

Brubaker KL, Entekhabi D, Eagleson PS. 1993. Estimation of continental precipitation recycling. Journal of Climate 6: 1077-1089.

Cadet DL, Nnoli O. 1987. Water vapour transport over Africa and the Atlantic Ocean during summer 1979. Quarterly Journal of the Royal Meteorological Society 113: 581-602.

De Rosnay P, Drusch M, Holmes T, Balsamo G, Scipal K, Andersson E, Bougeault P. 2008. ECMWF's contribution to the SMOS project. ECMWF Newsletter 115: 5-6, Spring 2008.

Fontaine B, Roucou P, Trzaska S. 2003. Atmospheric water cycle and moisture fluxes in the West African monsoon: mean annual cycles and relationship using NCEP/NCAR reanalysis. Geophysical Research Letters 30: 101029-101032.

Gong C, Eltahir EAB. 1996. Sources of moisture for rainfall in West Africa. Water Resources Research 32: 3115-3121.

Guichard F, Asencio N, Peugeot C, Bock O, Redelsperger J-L, Cui X, Garvet M, Lamptey B, Orlandi E, Sander J, Fierli F, Gaertner MA, Jones S, Lafore J-L, Morse A, Nuret M, Boone A, Balsamo G, De Rosnay P, Decharme B, Harris P, Bergès J-C. 2010. An intercomparison of simulated rainfall and evapotranspiration associated with a mesoscale convective system over West Africa. Weather and Forecasting 25: 37-60. DOI: 10.1175/2009WAF2222250.1.

Karbou F, Rabier F, Lafore J-P, Redelsperger J-L, Bock O. 2010. Global 4D-Var assimilation and forecast experiments using land surface emissivities from AMSU-A and AMSU-B. PartII: impact of adding surface channels on the African Monsoon during AMMA. Weather and Forecasting 25: 20-36. DOI: 10.1175/2009WAF2222244.1.

Marullo S, Santoleri R, Banzon V, Evans RH, Guarracino M. 2009. A diurnal-cycle resolving SST product for the tropical Atlantic: toward a bias-free diurnal-cycle resolving SST product combining microwave and infrared satellite data. Journal of Geophysical Research 115: C05011 pp. 18, DOI:10.1029/2009JC005466.

Meynadier R, Bock O, Guichard F, Boone A, Roucou P, Redelsperger J-L. 2010a. The West African Monsoon water cycle. Part I: a new hybrid water budget dataset. Journal of Geophysical Research, DOI:10.1029/2010JD013917 (in press).

Meynadier R, Bock O, Gervois S, Guichard F, Redelsperger J-L, Agustí-Panareda A, Beljaars A. 2010b. The West African Monsoon water cycle. Part II: assessment of NWP water budgets. Journal of Geophysical Research, DOI:10.1029/2010JD013919 (in press). 
Nicholson SE, Kim J, Ba MB, Lare AR. 1997. The mean surface water balance over Africa and its interannual variability. Journal of Climate 10: 2981-3002.

Nuret M, Lafore J-P, Bock O, Guichard F, Agustí-Panareda A, Ngamini J-B, Redelsperger J-L. 2008. Correction of humidity bias for Vaïsala RS80 sondes during AMMA 2006 observing period. Journal of Atmospheric and Oceanic Technology 25: 2152-2158. DOI: $10.1175 / 2008 J T E C H A 1103.1$.

Redelsperger J-L, Thorncroft C, Diedhiou A, Lebel T, Parker DJ,
Polcher J. 2006. African monsoon multidisciplinary analysis (AMMA): an international research project and field campaign. Bulletin of the American Meteorological Society 87: 1739-1746.

Roads J, Kanamitsu M, Stewart R. 2002. CSE water and energy budgets in the NCEP-DOE reanalysis II. Journal of Hydrometeorology 3: $227-248$.

Trenberth KE, Guillemot CJ. 1995. Evaluation of the global atmospheric moisture budget as seen from analyses. Journal of Climate 2255-2272. 